$\xi=-1$ 圆

\title{
Characteristics of Senior High School Students in the Utilization of School Library in Indonesia
}

\author{
*Dessy Harisanti ${ }^{1}$, Esti Putri Anugrah ${ }^{1}$ \\ Library Studies, Department of Engineering, Vocational Faculty, Universitas Airlangga, Surabaya, Indonesia \\ *Corresponding author: *Dessy Harisanty: Library Studies, Department of Engineering, Vocational Faculty, Universitas Air- \\ langga, Surabaya, Indonesia \\ *Corresponding author E-mail: dessyharisanty@gmail.com
}

\begin{abstract}
School library provides various facilities and services adjusted to the needs of students as library users. With the availability of various facilities and services in the school library, the students can choose the facilities and library services that want to be utilized to meet their needs in the school environment. This study aims to determine the characteristics of students in the utilization of school library. This research uses quantitative approach with descriptive analysis. The location of this research is in a library of a Senior High School (SMA) in Surabaya, the second largest city in Indonesia. The results of this study indicate that high school students in the use of school libraries have different characteristics. They more often visit the library during break time compared to other times. Students use the library for school work, and some students do other activities in the library. In the case of borrowing books, the students mostly only borrow one book, the borrowed book is in Bahasa Indonesia, and not many students borrow collections in foreign languages. From this research, it can also be seen that many collections that do not fit between the bookshelves and the catalog / OPAC. Thus, it makes the students prefer to search directly on the shelf instead of using the catalog / OPAC. On the other hand, it is also because the students are still confused in using OPAC.
\end{abstract}

Keywords: Characteristics of students, school library, library utilization

\section{Introduction}

Nowadays, human civilization has reached the age of the information society. In that era, information becomes a primary necessity in everyday life. Information is needed naturally in all activities performed by humans. Just as students feel, they make the information as a basic need for learning activities in the school environment. Therefore, they will continue to work hard to meet those needs by going to a place that is the center of information, one of which is the school library.

According to the International Federation of Library Association and Institutions (IFLA) [1], school libraries have the function of encouraging and enhancing student learning in schools by providing information and learning space within them. School libraries focus on the information with intellectual content, information literacy and social development. The school library is an important instrument for intellectual development. A wellstocked library is a repository of information, or a record of human experience that originally is just data and then converted into information, reported by Sivathaasan [2].

Given the importance of a school library, the government of Indonesia has also sought for the development of school library in every school in Indonesia. The Government of Indonesia has arranged it in the Law. Referring to the Law no. 43 of 2007 Article 23 concerning School Library, it is stated that schools or madrasah (Islamic School) should organize libraries with regard to the National Standards of Education [3].

School libraries provide library services and facilities adjusted to the characteristics of their users which are the students at school, because the library survival depends on the extent to which users are "fulfilled their needs or satisfied", reported by Kaushik [4]. The services and facilities provided by the school library make the visiting students utilize the library freely according to what they want not only driven on a single service or facility.

The results of a study conducted by Parveen in the library of India which evaluated in detail the type of information, sources and services used by students revealed that $63.54 \%$ of students visited the library to read newspapers while $42.70 \%$ of students visited the library every day $32.39 \%$ of students were not satisfied with existing library resources [5].

The results of the study by Obreg explained that the school library was not only used for reading, circulating (borrowing) or seeking information, but also a place for casual activities and socializing with fellow students [6]. Obreg also explained again that successful school libraries were not just libraries seen in general, but libraries were used like a living room inside a house.

Based on the two studies conducted abroad, it shows that students who visit the school library are not only fixated on formal learning or reading activities. However, they do activities in the school library in accordance with what they want by utilizing the facilities and services that have been provided. Referring to these two studies, this study was conducted with the aim to see how the 
characteristics of high school students in the utilization of school library which later the results of this study can be used by the school library to improve services and libraryfacilities that match the character of its users because basically the library must perform services that is user oriented.

\section{Method}

This research used quantitative approach. The quantitative approach used is descriptive. Descriptive analysis is used to describe the results of research in the form of existing data in the field descriptively.

The selected location of this research was in Senior High School (SMA) in Surabaya with the consideration that it was used as the basis for the selection or determination of the location because Surabaya is one of the largest cities in Indonesia. Thus, it was assumed that the freedom of information was wide open.

The target population in this study was high school students in Surabaya. High school students were selected because it was a period of adolescence. Adolescence is a period of transition from childhood to adulthood characterized by changes in physical, psychological, and psychosocial aspects.

The sampling technique used was cluster random sampling. The reason for using this technique was because the sample frame in the form of a list of individual names was not available, but the available one was the group / cluster list (school). Therefore, samples were drawn from the clusters (schools). After that, individuals were drawn, reported by Eriyanto [7].

Data collection techniques conducted in this study were: a) primary data collection, namely structured interviews to respondents. Besides through questionnaires, it was also conducted by probing which was used to find out more about the (considered) unique trends expressed by the respondents; B) secondary data collection which was data from related institutions such as high school data and student data to be researched either through websites, brochures, or other publications.

All collected primary data were processed using SPSS for descriptive statistics, especially for the purpose of displaying a single frequency table. The quantitative data that had been processed were then analyzed and interpreted theoretically. Qualitative data obtained through the probing results of the respondents were also used to sharpen the analysis.

\section{Findings}

\section{Length of visit}

The following data are intended to find out how long every time high school students in Surabaya visit the school library. The following table presents the crosstab between the length of visit and the intensity of visit of the senior high school students to the school library in Surabaya:

Table 1: Crosstab between Length of Visit and Intensity of Visit to School Library

\begin{tabular}{|c|c|c|c|c|c|}
\hline \multirow{2}{*}{ Length of Visit } & \multicolumn{4}{|c|}{ Intensity of Visit } & \multirow{2}{*}{ Total } \\
\hline & $1-2$ times & 3-4 times & 5-6 times & Uncertain & \\
\hline Less than 30 minutes & 42 & 8 & 1 & 24 & 75 \\
\hline More than 30 minutes & 16 & 2 & 5 & 6 & 29 \\
\hline Total & 112 & 34 & 11 & 43 & 200 \\
\hline
\end{tabular}

Source: Processed Primary data

Table 1 shows that most respondents visited the library for 15-30 minutes. This was because most users visit the library during their break time where the average length of break time of high school students is 15 - 30 minutes. As one student expressed:

"I usually come to the school library during break time. More often in the first session. So, I spend the whole time in the library ... Because in second session, I usually go to the cafeteria and pray. I am hungry at that time ... If it is in the morning, I always have breakfast, so I am not hungry in the first session ... ".

Despite the short time of break, there are several school libraries that extend the hours of operation, such as the Muhammadiyah library that opens at $6: 30$ to $4: 30 \mathrm{pm}$. The school library remains open for half a day on Saturdays where the school is only used for extracurricular activities.

From the data above, there were 29 respondents who used the school library for more than 30 minutes. Usually, they used the school library if there was no class or after school. This was because the break time was so short that the opening hours of the school library was extended to facilitate students in utilizing the school library to the fullest. Although school library operation hours had been extended, high school students who utilized the library were still not maximal. Here is the statement of one of the students:

"Well, I don't want to go there....it's time to go home, not to go to library.... I want to go home soon... I am tired....."

Based on the reason, the utilization of school library after school hours is considered less than optimal. This is because their school system is fullday-school, so they are tired. However, the effort that has been done by the school library is considered good enough in improving the quality of school library services where one of the indicators is physical evidence including the library operation hours.

\section{Student activities in the school library}

The data below is intended to find out the activities of high school students in Surabaya in the school library. The data are presented in the table below:

Table 2: Activities at the School Library

\begin{tabular}{|l|l|l|}
\hline Activities & Frequency & Percentage \\
\hline Discussion & 112 & $56 \%$ \\
\hline Doing Assignment & 86 & $43 \%$ \\
\hline
\end{tabular}




\begin{tabular}{|l|l|l|}
\hline Reading popular readings & 37 & $18.5 \%$ \\
\hline Searching for general information & 45 & $22.5 \%$ \\
\hline Borrowing & 61 & $30.5 \%$ \\
\hline Dating & 3 & $1.5 \%$ \\
\hline Relaxing & 60 & $30 \%$ \\
\hline Others & 7 & $3.5 \%$ \\
\hline
\end{tabular}

Source: Processed Primary data

Table 2 shows that school libraries are widely used as discussion venues (56\%), a place to do assignments (43\%), anda place to borrow books (30.5\%). This is in accordance with the purpose of the school library that is to support the existing educational process in the school. Thus, the library materials are adjusted to its purpose. But, this does not mean merely containing the textbooks used in the teaching and learning process, but also the materials for recreational purposes, popular science, and others. Darmono added that, in general, the comparison of library materials in school libraries is $60 \%$ of the collection of supporting curriculum including textbooks, required books, and supporting books, and $40 \%$ of general collections of fiction as well as books on other general knowledge [8]. This is because the real educational process is not just to provide the existing knowledge from the teacher to the students, but also to stimulate students to always develop themselves, and improve their talents and abilities. It is important since the function of the library is as an educative, informative, research, and recreational facility.

However, based on the results of probing, not all the discussions conducted by respondents had academic nuance. There were many respondents who discussed about novels, gossip, and even the television show. Here is the statement of one of the respondents:

"Usually I discuss about TV shows, sometimes I talk about gossip like now about Luna Maya and Ariel. Since it is exciting in the library, the temperature is cool, because there is an AC. So, I like to stay there. But, sometimes we also discuss about novels or books that are popular just like yesterday, we discussed Twilight. We rarely talk about school materials. We did it before though."

In addition, many respondents also did casual activities in the library. They just wanted to enjoy the peace and freshness of the air conditioner. There were also those who dated in the library although the percentage of this activity was relatively small. Based on the acknowledgment of one of the students who did not want to mention his name, he said that he accompanied his girlfriend to the library so he has time to spend time together.

Table 3: Number of books borrowed (per month)

\begin{tabular}{|l|l|l|}
\hline Number of books borrowed (per month) & Frequency & Percentage \\
\hline Less than 2 copies & 126 & 63.0 \\
\hline $2-3$ copies & 57 & 28.5 \\
\hline $4-5$ copies & 10 & 5.0 \\
\hline More than 5 copies & 6 & 3.0 \\
\hline Never & 1 & 0.5 \\
\hline Total & 200 & 100.0 \\
\hline
\end{tabular}

Source: Processed Primary data

Table 3 shows that the majority of books borrowed by respondents per month are less than 2 copies which is $63.0 \%$. $28.5 \%$ of respondents borrowed 2-3 copies, 5.0\% respondents borrowed 4-5 copies, $3.0 \%$ respondents borrowed more than 5 exemplars, and $0.5 \%$ of respondents never borrowed book. Lending collection in the school library still seems not maximum.

Based on the results of probing conducted to the respondents, many respondents borrowed books in the library less than 2 copies with various reasons. The following statement is from one of the respondents:

"How can I borrow many books? If I do not have an assignment, I don't borrow books because I prefer to read in the internet while relaxing. I borrow book if there is a book that I like, but I rarely do that since the books here do not have many variations"
Based on the results of the probing, then the role of teachers to utilize the library collection are very substantial. Therefore, there should be cooperation between teachers and libraries to maximize the utilization of libraries to support teaching and learning activities.

Table 4: Language

\begin{tabular}{|l|c|c|}
\hline Language & Frequency & Percentage \\
\hline Bahasa Indonesia & 178 & 89.0 \\
\hline English & 15 & 7.5 \\
\hline Others & 7 & 3.5 \\
\hline Total & 200 & 100.0 \\
\hline
\end{tabular}

Source: Processed Primary data

Table 4 shows the language of book collections possesed by the library. The majority of respondents who answered to select Indonesian language was $89.0 \%$, English was $7.5 \%$, and other answers such as Mandarin and Germany were $3.5 \%$. The average of the respondents admitted that even reading book in the Indonesian language is still rare let alone books in foreign languages. Thus, the language factor affects the behavior of students' information discovery.

According to the results of the probing, the respondents said that the books collection possesed by the library are limited and many of them are in Bahasa Indonesia. Here is the statement of one of the respondents:

"Most collection of books in the library here is in Bahasa Indonesia, it is rare to find the books in English. Perhaps, there are more Arabic tafseer books, there are a lot of novels too. Because I do not how to speak English well, it is not a problem if the collection in this library is in Bahasa Indonesia. I can easily understand the content anyway."

Based on the probing result, the ability of foreign languages is an obstacle in utilizing the collection. In addition to the ability of foreign languages, the availability of collections in the school library is also mostly in Bahasa Indonesia. The availability of collections in Bahasa Indonesia is an attraction for high school students because it is easier for them to understand the reading.

Table 5: Utilization of foreign language collection per month

\begin{tabular}{|l|c|c|}
\hline Utilization of Foreign Language Collection & Frequency & Percentage \\
\hline 1-2 times & 82 & 41.0 \\
\hline 3-4 times & 21 & 10.5 \\
\hline 5-6 times & 2 & 1.0 \\
\hline Never & 95 & 47.5 \\
\hline Total & 200 & 100.0 \\
\hline
\end{tabular}

Source: Processed Primary data

Table 5 shows the utilization of foreign collections per month. The majority of respondents who said they never utilize which was about $47.5 \%$, respondents who answered 1-2 times was $41.0 \%$, respondents who answered 3-4 times were $10.5 \%$, respondents who answered 5-6 times were $1.0 \%$. Here is the probing result with one of the respondents:

"Well... even reading in Bahasa Indonesia is not interesting thing to do, let alone reading in English, it is very uninteresting even just opening it. So, I almost never borrow books in English, I prefer in Bahasa Indonesia. I love Indonesia” 
For senior high school students, the use of foreign language in book collection takes more time to understand the information contained in it because they must translate it first, while the collection in Bahasa Indonesia is understood more quickly. This is in accordance with the theory of rational choice. According to this theory, humans have a tendency to compare the profits they will gain from each of the ways in which they achieve their goals so that they can choose one of the best options that is capable of providing relative advantages, especially in terms of time and cost, reported by Prabha [9]. According to Friedman, the individual estimates cost and benefit based on preference and the value he believes.

Table 6: Compatibility of Books on Shelves with Catalog

\begin{tabular}{|l|l|l|}
\hline $\begin{array}{l}\text { Book Compatibility on } \\
\text { Shelves with Catalog }\end{array}$ & Frequency & Percentage \\
\hline Always & 29 & 14.5 \\
\hline Rarely & 114 & 57.0 \\
\hline Do not know & 57 & 28.5 \\
\hline Total & 200 & 100.0 \\
\hline
\end{tabular}

Source: Processed Primary data

Table 6 above shows that the majority (57\%) of respondents answered that there was rarely suitability between the books on shelves and the catalogs. Some of the respondents (28.5\%) did not know because they never used the catalog either paper catalog or online, and respondents who answered that there was a compatibility between the books on the shelf and the catalog were $14.5 \%$.

Catalogs in libraries have functions as a medium of finding library materials possessed by libraries. Catalogs that are available in school libraries that serve as research sites are cards catalog and OPAC (Online Public Access Catalog) catalog. The card catalog is made of paper measuring of $7.5 \mathrm{~cm} \times 12.5 \mathrm{~cm}$ while the OPAC catalog is the result of the implementation of the library automation system which is online catalog. Catalog that serves as an information tracking tool certainly functions to facilitate the user to find the location of the required collection. However, based on the above data, it is seen that most high school students in Surabaya considered that books on the shelf are rarely accurate with the location shown in the catalog. This is due to the alignment on the shelf that does not fit the rules.

According to the rules, the books lined on the shelf must be in accordance with the calling number of the book ranging from the smallest to the largest so that the placement of the book is sequence. Alignments that are inconsistent with this rule are mostly because the users return the book they have taken to the wrong shelf. If any other users are searching for the book, then it is not found because the place of the book is changed. Therefore, there should be an appeal to the users so that after utilizing the book, it should not be directly returned to the shelf but it is placed on the table or in place that has been provided by the library official.

The following table presents the crosstab between how to access with the duration of searching on the shelf:

Table 7: Crosstab between How to Access with the Duration of Searching in Shelves

\begin{tabular}{|c|c|c|c|c|c|}
\hline \multirow[b]{2}{*}{ How to Access } & \multicolumn{4}{|c|}{ Duration of Searching in Shelves } & \multirow[b]{2}{*}{ Total } \\
\hline & \begin{tabular}{|l}
$\begin{array}{l}\text { Less than } 10 \\
\text { minutes }\end{array}$ \\
\end{tabular} & 10-20 minutes & $\begin{array}{l}\text { Less than } 10 \\
\text { minutes }\end{array}$ & $10-20$ minutes & \\
\hline Through the catalog / OPAC & 4 & 3 & 1 & 0 & 8 \\
\hline Ask the librarian & 14 & 10 & 1 & 0 & 25 \\
\hline Search directly on the shelf & 71 & 76 & 6 & 6 & 159 \\
\hline $\begin{array}{l}\text { Ask the librarian \& Search directly on the } \\
\text { shelf }\end{array}$ & 2 & 3 & 0 & 1 & 6 \\
\hline $\begin{array}{l}\text { Through catalog / OPAC \& Search directly } \\
\text { on the shelf }\end{array}$ & 1 & 0 & 0 & 0 & 1 \\
\hline $\begin{array}{l}\text { Ask the librarian \& Search directly on the } \\
\text { shelves \& from friends' information }\end{array}$ & 1 & 0 & 0 & 0 & 1 \\
\hline Total & 93 & 92 & 8 & 7 & 200 \\
\hline
\end{tabular}

Source: Processed Primary data

Based on the above data, it shows that most users who accessed through the catalog / OPAC and asked the library staff experienced less than 10 minutes of searching while users who search directly to the shelves mostly experience a long search of 10-20 minutes. Thus, the collection search by using tools is quicker to get the required collection.

The majority $(46.5 \%)$ of the duration that the respondents needed to search the shelves is less than 10 minutes. Respondents who answered 10-20 minutes were $46.0 \%, 21-30$ minutes were $4.0 \%$, and more than 30 minutes were $3.5 \%$.

Table 3 above shows how to access the information needed by the respondent. The majority of respondents who answered using direct way to the shelves were $79.0 \%$. High school students still did not understand how to utilize the library. They did not understand how to find the collections. Therefore, they directly went to the shelves and then searched for the collections they needed one by one. Respondents who asked the library officer were $12.5 \%$. For high school students who were not shy and did not hesitate to ask, they immediately asked the collection they needed to the librarian.

Based on the results of probing of how to access the information, the respondents in the library felt easier to directly look to the bookshelf because many of the them did not know how to use the catalog. Here is the statement of one of the respondents:

"Oh my god, I don't know what catalog is, let alone its function. If I want to borrow or look for a book, I just go directly to the shelf, if I don't find it, I ask the librarian. As simple as that."

Respondents who used the catalog / OPAC were $4.0 \%$. Those who used OPAC / catalog were those who already understand how to use it. Respondents who answered asking the librarians and searching directly to the shelves were $3.0 \%$. From the above data, the collection search through catalog search tool / OPAC is not maximally utilized. Here are the reasons of access through the catalog / OPAC for high school students in Surabaya:

Table 8: Access via catalog / OPAC

\begin{tabular}{|l|c|c|}
\hline Access via catalog / OPAC & Frequency & Percentage \\
\hline Easy & 47 & 23.5 \\
\hline Complicated & 21 & 10.5 \\
\hline Confusing & 75 & 37.5 \\
\hline Do not know & 57 & 28.5 \\
\hline Total & 200 & 100.0 \\
\hline
\end{tabular}

Source: Processed Primary data 
Table 8 above shows the access through the catalog / OPAC. The majority of respondents answered that it was confusing $(37.5 \%)$. The following probing result is from one of the respondents: "Oh my God, basically, I am a person who don't like complicated things so accessing the catalog is not interesting. I don't even know how to use it, so it makes me more confused. It is better to use instant method, and it is faster to find it on the shelf, there is already the subs parts of the subject right?"

High school students are introduced to the books collection of school library through the catalog / OPAC at the time of the new student orientation. Given the large number of students with the limited catalog / OPAC props, the introduction of this period is not enough. Therefore, it needs to be added with the users' education about how to utilize the school library, especially about collection search so that the information can be obtained easily. Education for the users can be conducted at any time both on schedule and on demand. It also needs to be installed about how to search through the catalog /OPAC near the searcher tool so that for high school students who are shy to ask, they can read the manual to use the catalog / OPAC. Respondents who answered that they did not know how to access OPAC were $28.5 \%$, the ones who answered that it was easy were $23.5 \%$, the ones who answered that it was complicated were $10.5 \%$. Respondents answered that it was easy because they are not shy to ask about how to use OPAC / catalog.

\section{Conclusion}

High school students in utilizing the school libraries have different characteristics in accordance with their wishes in utilizing the facilities or services provided by the library. It is seen that they mostly visit the library during break time. Students visit the library mostly to do assignment, but they also do other activities in the library, such as discussions, reading books, finding information, borrowing books, just relaxing, or some are dating in the library. In the case of borrowing books, mostly students borrowed 1 book. The borrowed book is in Bahasa Indonesia. For the utilization of book collections in foreign languages, each student rarely borrows a collection in a foreign language. On the other hand, students assume that sometimes the books on the shelves do not fit with the catalog of books. It can be seen from the students who mostly search directly on the shelf rather than through the catalog / OPAC first. This is due to the catalog / OPAC access that students find confusing. From the characteristics of high school students in utilizing the school library, there are some shortcomings of services or facilities provided by the library. The shortcoming is the reason why the students do not use the service or facility. School libraries can improve their facilities and services, so they can be fully utilized by high school students.

\section{References}

[1] IFLA. IFLA School Library Guideline. 2015. Available at https://www.ifla.org/files/assets/school-libraries-resourcecenters/publications/ifla-school-library-guidelines.pdf

[2] N. Sivathaasan. Personal Characteristics and Use of Library Facilities: A Special Reference to Faculty of Management Studies and Commerce University of Jaffna Sri Lanka. European Journal of Business and Innovation Research 2013; 1(1): 72-78. Available at http://www.eajournals.org/wp-content/uploads/PERSONALCHARACTERISTICS-AND-USE-OF-LIBRARY-FACILITIES

[3] Indonesia. Undang-undang No. 43 Tahun 2007 tentang Perpustakaan Sekolah. 2007.

[4] A. Kaushik. Emerging Library User Characteristics, Behaviors and Expectations Convergence in Collection Management and Technical Services: A Case Study of C.C.S. University, Meerut, International Journal of Pharmaceutical Science Invention 2013; 2(6): 55-67. Available at http://www.ijpsi.org/Papers/Vol2(6)/Version-1/K0261055067.pdf
[5] K. Parveen. Use of library resources by the students of Indian Institute of Management, Rohtak, India, International Journal of Library Science and Research 2013; 3: 7-12, Available at http://tjprc.org/publishpapers/2-48-13596209652.Use $\% 20 \% 20$ of $\% 20$ library.full.pdf

[6] Obreg. Libraries in Schools: Essential Contexts for Studying Organizational Change and Culture. Library Trend 2009; 58(1): 9 25 Available at https://muse.jhu.edu/article/361472

[7] Eriyanto.Teknik Sampling: Analisis Opini Publik. Yogyakarta: LkiS; 2007.

[8] Darmono.Perpustakaan Sekolah: Pendekatan Aspek Manajemen dan Tata Kerja. Jakarta: Grasindo; 2007.

[9] Prabha, et.al. What is enough? Satisficing information needs, Journal of Documentation 2007; 63(1): 74-89. Available at http://www.oclc.org/publications/archive/2007/prabhasatisfacing.pdf 